\title{
Acari of lizards from Atlantic Forest in northeastern Brazil
}

\section{Camila Nascimento de Oliveira' ${ }^{1,3}$, Ikaro Henrique Mendes Pinto Campos ${ }^{1}$, Jaqueline Bianque de Oliveira ${ }^{2}$, Geraldo Jorge Barbosa de Moura ${ }^{3}$}

1 Laboratório de Animais Peçonhentos e Toxinas, Universidade Federal de Pernambuco. Av. Prof. Moraes Rego, 50670-901 Recife, PE, Brasil

2 Laboratório de Parasitologia, Departamento de Biologia, Universidade Federal Rural de Pernambuco. Rua Dom Manoel de Medeiros, 52171-900 Recife/PE, Brasil

3 Laboratório de Estudos Herpetológicos e Paleoherpetológicos, Universidade Federal Rural de Pernambuco. Rua Dom Manoel de Medeiros, 52171-900 Recife/PE, Brasil

Corresponding author: Camila N. Oliveira (camilanascimentov@yahoo.com.br)

Academiceditor:A.M.Leal-Zanchet | Received 15 March2018 | Accepted23 December 2018 | Published 11 April2019

Citation: de Oliveira CN, Mendes Pinto Campos IH, Bianque de Oliveira JB, de Moura GJB (2019) Acari of lizards from Atlantic Forest in northeastern Brazil. Neotropical Biology and Conservation, 14(1): 109-116. https://doi. org/10.3897/neotropical.14.e34840

\begin{abstract}
Although mites are often associated with reptiles, there is little information available about parasites of lizards in Brazil. The aim of this study was to identify the ectoparasites of the lizards Kentropyx calcarata (Squamata: Teiidae), Hemidactylus mabouia (Squamata: Gekkonidae) and Tropidurus hispidus (Squamata: Tropiduridae) from northeastern Brazil. The lizards were captured during the dry season at Mata de Tejipió, a fragment of Atlantic Forest, located in the municipality of Recife, state of Pernambuco, northeastern Brazil. Eutrombicula sp. (Acari: Trombiculidae), Geckobia hemidactyli and Geckobiella harrisi (Acari: Pterygosomatidae) were found associated with adult lizards of K. calcarata, H. mabouia, and T. hispidus, respectively. Mites were found in skin folds of the throat and post femoral regions (Eutrombicula sp.), "mite-pockets" (G. harrisi); and in axillary, dorsal, ventral and pelvic regions (G. hemidactyli). In Brazil, this study widens the known geographical distribution of Geckobiella harrisi on T. hispidus and G. hemidactyli on H. mabouia. In addition, K. calcarata is recorded as a new host of Eutrombicula sp. These findings show the importance of ectoparasites as a tool for ecological and biogeographic studies.
\end{abstract}

\section{Keywords}

Eutrombicula, Geckobia hemidactyli, Geckobiella harrisi, mites, Squamata 


\section{Introduction}

Studies about host-parasite interactions are important to comprehend ecological relationships, providing information about the biology and conservation of the species (Bush et al. 2001). Despite this, host-parasite relationships between Acari and reptiles have received limited attention (Fajfer, 2012). Several families of mites are described as reptile ectoparasites (Fajfer, 2012), but only the families Harpirhynchidae (Fain, 1964), Heterozerconidae (Flechtmann and Johnston, 1990), Trombiculidae (Carvalho et al. 2006; Rocha et al. 2008; Delfino et al. 2011; Menezes et al. 2011), Pterygosomatidae (Delfino et al. 2011) and Macronyssidae (Barbosa et al. 2006) have been recorded from Brazilian Squamata. In lizards, morphological characteristics that facilitate the attachment of ectoparasites are the "mite-pockets" (Bertrand and Modrý, 2004), imbricate scales (Menezes et al. 2011), skin folds (Bauer et al. 1990; Carvalho et al. 2006), axillary and post-femoral regions (Delfino et al. 2011). "Mite-pockets" are structures formed by skin folds popliteal position, which is open when extended and closed when it is flexed, housing damaging mites (Bertrand and Modrý, 2004).

The lizard Kentropyx calcarata Spix 1825 (Squamata, Teiidae) has a wide distribution in forested habitats in the Amazon and the Atlantic Forest (Avila-Pires, 1995), but it can also be associated with forest edge (Morato et al. 2011) and disturbed areas (Prudente et al. 2013). Hemidactylus mabouia (Moreau de Jonnès 1818) (Squamata, Gekkonidae) is an exotic species of lizard from Africa, without micro-environmental specificity that shows a close relationship with anthropic and perianthropic environments and occupies microhabitats, such buildings (Vrcibradic et al. 2011). Tropidurus hispidus (Spix 1825) (Squamata, Tropiduridae) is found in open areas but it can also be associated with forest edge (Morato et al.2011) or be a generalist regarding to its habitat (Van Sluys et al. 2004; Miranda et al. 2012). This species is in constant contact with human inhabited areas (Vitt et al.2008).

In the current study, we documented mites infesting free-living lizards K. calcarata, T. hispidus and $H$. mabouia in a fragment of the Brazilian Atlantic Forest. This study was developed at Mata de Tejipió $\left(08^{\circ} 05^{\prime} 45.59^{\prime \prime} S ; 34^{\circ} 57^{\prime} 04.91^{\prime \prime} \mathrm{W}\right)$, a fragment of Atlantic Forest located in the municipality of Recife, state of Pernambuco, northeastern Brazil. The area has 172 ha of tropical rain forest in secondary stages of regeneration (Feitosa, 2004), including areas of buildings reserved for military activities. The capture of the lizards occurred during the dry season, with the use of pitfall traps, drift fences and by active search, authorized by Instituto Chico Mendes de Conservação da Biodiversidade (ICMBio No 31795-1) and approved by Comitê de Ética e Experimentação Animal da Universidade Federal Rural de Pernambuco (CEUA-UFRPE No 064/2013).

Captured lizards were restrained manually, examined visually, and all detected ectoparasites were collected and preserved in $70 \%$ ethanol. The anatomical sites occupied by ectoparasites were recorded. Lizards were released at the same locations of the captures. 

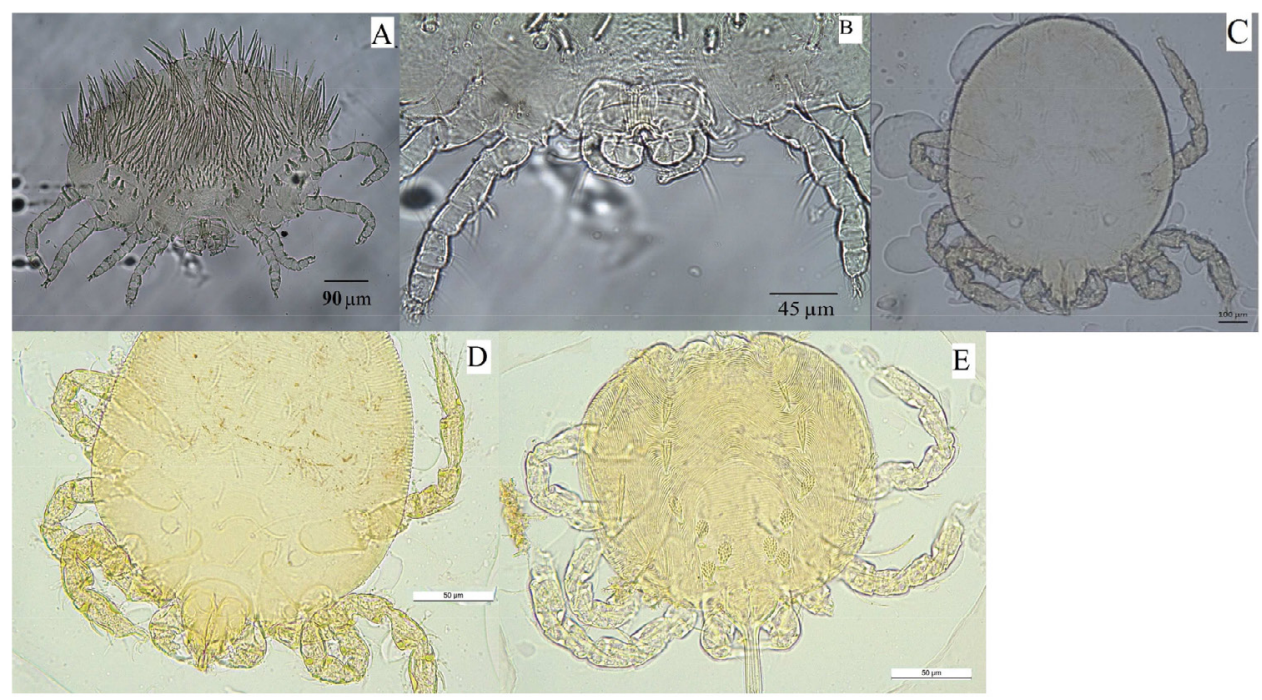

E

Figure 1. Light microscopy photographs of the mite specimens found infesting lizards in the Atlantic Forest, northeastern Brazil. Geckobia hemidactyli (A and B); Eutrombicula sp. (C and D) and Geckobiella harrisi (E).

Mites were mounted on permanent slides in Hoyer's medium for subsequent identification based in Lawrence, 1936; Bochkov and Mironov, 2000 (Geckobia hemidactyli); Jack, 1964 (Geckobia hemidactyli and Geckobiella harrisi); Paredes-León et al. 2012 (Geckobiella harrisi); Brennan and Goff, 1977; Loomis and Wrenn, 1984; Daniel and Stekol'nikov, 2004 (Eutrombicula sp.). Mites were deposited in the Coleção Parasitológica do Laboratório de Parasitologia da Universidade Federal Rural de Pernambuco (LAPAR-UFRPE), Eutrombicula sp. (CP-LAPAR 79), Geckobia hemidactyli (CP-LAPAR 80) and Geckobiella harrisi (CP-LAPAR 81).

Twenty-nine lizard specimens were captured including Tropidurus hispidus (Squamata: Tropiduridae) $(\mathrm{n}=13)$, Hemidactylus mabouia (Squamata: Gekkonidae) $(\mathrm{n}=11)$ and Kentropyx calcarata (Squamata: Teiidae) $(\mathrm{n}=5)$. Specimens of K. calcarata were captured inside the forest, and the other lizards were captured at the edge of the forest in proximity to buildings.

Three adult lizards (10.3\%) were infested with mites (larvae and adults). Eutrombicula sp. (Acari: Trombiculidae) $(\mathrm{n}=28)$, Geckobia hemidactyli Lawrence $1936(\mathrm{n}=18)$ and Geckobiella harrisi Davidson 1958 (Acari: Pterygosomatidae) $(\mathrm{n}=2)$ (Figure 1) were found on K. calcarata, H. mabouia and T. hispidus, respectively. Mites were found on skin folds of the throat and post femoral regions (Eutrombicula sp.), and in axillar, dorsal, ventral and pelvic regions (G. hemidactyli). Geckobiella harrisi was found in the mite-pockets.

Little information is available about the parasites of lizards in Brazil, particularly in the northeast region. The infestation prevalence recorded in this study is lower than reported in other studies with lizards of different habitats from Brazil (Cunha-Barros and 
Rocha, 2000; Rocha et al. 2008; Delfino et al. 2011) where the infestation prevalence of E. alfreddugesi ranges from 5\% to 100\% (Delfino et al. 2011). According to Fajfer (2012), the highest and most varied ectoparasite prevalence is noted for temporary ectoparasites of reptiles. In this study, both permanent (G. hemidactyli and G. harrisi) and temporary ectoparasites (Eutrombicula) were identified, which was also recorded by Delfino et al. (2011) on T. hispidus from the state of Ceará, northeastern Brazil.

Kentropyx calcarata represents a new record for Eutrombicula sp. The genus Eutrombicula comprises nearly 80 species into six groups involving 30 unnamed species (Loomis and Wrenn, 1984; Daniel and Stekol'nikov, 2004). According to Daniel and Stekol'nikov (2004), further taxonomic investigations and descriptions of new Eutrombicula species are needed, especially in South America. The parasitism by larvae (chiggers) of Eutrombicula has been reported in Brazil on Mabuya agilis Raddi 1823, M. macrorhyncha Hoge 1947, Cnemidophorus littoralis Rocha, Araújo, Vrcibradic \& Costa 2000, Ameiva ameiva Linnaeus 1758 (Cunha-Barros and Rocha 2000, Cunha-Barros et al. 2003), T. hispidus, T. semitaeniatus Spix 1825, T. erythrocephalus Rodrigues 1987, T. cocorobensis Rodrigues 1987, T. itambere Rodrigues 1987, T. oreadicus Rodrigues 1987, T. torquatus Wied 1820 (Carvalho et al. 2006, Rocha et al. 2008, Delfino et al. 2011, Menezes et al. 2011), Plica plica (Linnaeus 1758) and P. umbra (Linnaeus 1758) (Gomides et al. 2015). This diversity of parasitized hosts, including humans, indicates that parasitism by Eutrombicula is not host specific (Clopton and Gold 1993, Fajfer 2012).

Geckobia hemidactyli is a parasite of Gekkonidae, including H. mabouia, H. tasmani Hewitt, 1932, H. frenatus Schlegel, 1836 and H. mercatorius Gray, 1842 in Africa, Asia, Mediterranean and America (Fajfer, 2012). In the American continent the parasitic association between $G$. hemidactyli and H. mabouia was recorded in Puerto Rico, the Caribbean, Colombia (Martínez-Rivera et al. 2003), the United States (Corn et al. 2011) and northern Brazil (Martínez-Rivera et al. 2003). G. hemidactyli is a common parasite of H. mabouia, and therefore MartínezRivera et al. (2003) suggested that the distribution of the mite followed H. mabouia in its geographical expansion throughout the Americas.

Introduction and establishment of exotic vertebrate parasites into any new environment usually leads to increased abundance and diversity of the local parasite fauna, resulting in the introduction of pathogens that could impact the health of local wildlife, domestic animals, and humans (Corn et al. 2011). This is the first record of natural infestation by G. hemidactyli on H. mabouia in northeastern Brazil. According to Martínez-Rivera et al. (2003) these findings serve as evidence for the importance of ectoparasites as a tool for biogeographic and ecological studies.

In the American continent, the genus Geckobiella includes eleven species identified as lizard parasites with main hosts being the families Iguanidae, Phrynosomatidae and Tropiduridae (Paredes-León et al. 2012). In Brazil, the first record of Geckobiella harrisi was made by Davidson (1958) in a tropidurid lizard of the species Plica plica (Linnaeus, 1758) from the state of Pará. Delfino et al. (2011) reported 
the occurrence of Geckobiella sp. on T. hispidus from Ceará state. Geographic distribution of G. harrisi in Brazil is now extended to Pernambuco state.

In other studies, chiggers were found in axillary, ventral and dorsal regions, tail, and cloaca (Cunha-Barros and Rocha, 2000; Delfino et al. 2011) and the main infestation sites were the mite-pockets and post femoral region in different species of lizards (Carvalho et al. 2006; Rocha et al. 2008; Delfino et al. 2011). Apparently mite-pockets restrict the distribution of chiggers on the lizard's body, reducing damage (Bauer et al. 1990). In the present study, G. harrisi was found in the mitepockets, although pterygosomatids are not usually found in this site (Delfino et al. 2011). According to Fajfer (2012), despite living under the lizard scales, pterygosomatids may also occur in "pocket-like structures" and in completely unprotected sites on the host's body. Imbricate scales and the presence and morphology of mite-pockets influence ectoparasitism in lizards (Cunha-Barros and Rocha, 2000; Bertrand and Modrý, 2004; Carvalho et al. 2006; Menezes et al. 2011). The pattern of scales is very characteristic in K. calcarata and mite-pockets are absent. Mites of lizards can occupy a wide range of parasitic niches and most species are very specific of the location in their host (Fajfer, 2012). In the study made by Delfino et al. (2011), Geckobiella sp. occurred uniformly under the scales throughout the body of T. hispidus, and mite species was found on same host specimen as E. alfreddugesi although they did not occupy the same infestation site. Geckobia hemidactyli was found in specimens of $H$. mabouia on the ventral surface, axilla, groin and tail (Martínez-Rivera et al. 2003). In adult lizards, mites are particularly abundant on body parts that come in contact during mating (ventral and dorsal surface, axilla, groin and tail) facilitating the transmission (Martínez-Rivera et al. 2003).

According to Martínez-Rivera et al. (2003), sexual contact or other prolonged and direct physical interaction is the most likely way for a host to acquire Geckobia mites. Mites and ticks are vectors of several infectious diseases and may cause direct impact (dermatitis and anemia) on the health of the lizards (Fajfer, 2012). Despite this, parasitized lizards studied here did not present any evidence of skin damage due to external parasites. E. alfreddugesi has previously been found on humans (Clopton and Gold, 1993) and infested lizards may be part of its natural life cycle. Further research of mite infestations in lizards in Brazil is needed to understand the life cycle of these mites and the potential role of lizards as reservoirs of mites infesting humans. The results obtained show the importance of considering the host and parasite relationship as a relevant study tool, since it is possible to evidence patterns of historical biogeography, as well as morphological, physiological and ecological factors determining species distribution.

\section{Acknowledgments}

We would like to thank the reviewers for their contribution to the quality of the published paper. 


\section{References}

AVILA-PIRES, T.C.S. 1995. Lizards of brazilian Amazonia (Reptilia: Squamata). Zoologische verhandelingen, 299(1): 1-706.

BARBOSA, A.R.; SILVA, H.; ALBUQUERQUE, H.N.; RIBEIRO, I.A.M. 2006. Contribuição ao estudo parasitológico de jibóias, Boa constrictor constrictor Linnaeus, 1758, em cativeiro. Revista de biologia e ciências da terra, 6(2): 1-18.

BAUER, A.M.; RUSSEL, A.P.; DOLLAHON, N.R. 1990. Skin folds in gekkonid genus Rhacodactylus: a natural test of damage limitation hypothesis of mite pocket function. Canadian Journal of Zoology, 68(6): 1196-1201. https://doi.org/10.1139/z90-178

BERTRAND, M.; MODRÝ, D. 2004. The role of mite pocket-like structures on Agama caudospinosa (Agamidae) infested by Pterygosoma livingstonei sp. n. (Acari: Prostigmata: Pterygosomatidae). Folia Parasitologica, 51(1): 61-66. https://doi.org/10.14411/fp.2004.009

BOCHKOV, A.V.; MIRONOV, S.V. 2000. Two new species of the genus Geckobia (Acari: Pterygosomatidae) from geckons (Lacertilia: Gekkonomorpha) with a brief review of host-parasite associations of the genus. Russian Journal of Herpetology, 7(1): 51-58.

BRENNAN, J.M.; GOFF, M.L. 1977. Keys to the genera of chiggers of the Western Hemisphere (Acarina: Trombiculidae). The Journal of parasitology, 63: 554-566. https://doi. org/10.2307/3280021

CARVALHO, A.L.G.; ARAÚJO, A.F.B.; SILVA, H.R. 2006. Patterns of parasitism by Eutrombicula alfreddugesi (Oudemans) (Acari, Trombiculidae) in three species of Tropidurus Wied (Squamata, Tropiduridae) from Cerrado habitat of Central Brazil. Revista Brasileira de Zoologia, 23(4): 1010-1015. https://doi.org/10.1590/S0101-81752006000400005

CORN, J.L., MERTINS, J.W.; HANSON, B.; SNOW, S. 2011. First reports of ectoparasites collected from wild-caught exotic reptiles in Florida. Journal of Medical Entomology, 48(1): 94-100. https://doi.org/10.1603/ME10065

CLOPTON, R.E.; GOLD, R.E. 1993. Distribution and Seasonal and diurnal activity patterns of Eutrombicula alfreddugesi (Acari: Trombiculidae) in a forest edge ecosystem. Journal of Medical Entomology, 30: 47-53. https://doi.org/10.1093/jmedent/30.1.47

CUNHA-BARROS, M.; ROCHA, C.F.D. 2000. Ectoparasitism by chigger mites (Eutrombicula alfreddugesi: Trombiculidae) in a restinga lizard community. Ciência e Cultura, 52(2): 108-113.

CUNHA-BARROS, M.; VAN SLUYS, M.; VRCIBRADIC, D.; GALDINO, C.A.B.; HATANO, F.H.; ROCHA, C.F.D. 2003. Patterns of infestation by chigger mites in four diurnal lizard species from a restinga habitat (Jurubatiba) of Southeastern Brazil. Brazilian Journal of Biology, 63(3): 393-399. https://doi.org/10.1590/S1519-69842003000300005

DANIEL, M.; STELKOLNIKOV, A.A. 2004. Chigger mites of the genus Eutrombicula Ewing, 1938 (Acari: Trombiculidae) from Cuba, with the description of three new species. Folia Parasitologica, 51(4): 359-366. https://doi.org/10.14411/fp.2004.045

DAVIDSON, J.A. 1958. A new species of lizard mite and a generic key to the family Pterygosomidae (Acarina, Anystoidea). Proceedings of the Entomological Society of Washington, 60:75-79. https://doi.org/10.14411/fp.2004.045

DELFINO, M.M.S.; RIBEIRO, S.C.; FURTADO, I.P.; ANJOS, L.A.; ALMEIDA, W.O. 2011. Pterygosomatidae and Trombiculidae mites infesting Tropidurus hispidus (Spix, 1825) 
(Tropiduridae) lizards in northeastern Brazil. Brazilian Journal of Biology, 71(2): 549555. https://doi.org/10.1590/S1519-69842011000300028

FAIN, A. 1964. Les Ophioptidae Acariens parasites dês ecailles des serpents (Trombidiformes). Bulletin de I'lnstitut Royal des Sciences Naturelles de Belgique, Entomologie, 40: 1-57. FAJFER, M. 2012. Acari (Chelicerata) - parasites of reptiles. Acarina, 20(2): 108-129.

FEITOSA, A.A.N. 2004. Diversidade de espécies arbóreas associada ao solo em toposseqüência de fragmento de Mata Atlântica de Pernambuco. Recife, PE. Dissertação de mestrado. Universidade Federal Rural de Pernambuco, 102 p.

FLECHTMANN, C.H.W.; JOHNSTON, D.E. 1990. Zeterohercon, a new genus of Heterozerconidae (Acari: Mesostigmata) and the description of Zeterohercon amphisbaenae n. sp. from Brazil. International Journal of Acarology, 16(3): 143-148. https://doi. org/10.1080/01647959008683526

GOMIDES, S.C.; MATURANO, R.; DAEMON, E.; GARCIA P.C.A.; RODRIGUES M.T. 2015. New reports of Acari ectoparasites on lizards of the genus Plica (Squamata: Tropiduridae) and a list of parasites known from this genus. Salamandra, 51(2): 195-198.

JACK, K.M. 1964. Leg-chaetotaxy with special reference to the Pterygosomidae (Acarina). Annals of the Natal Museum, 16(1): 152-171.

LAWRENCE, R.F. 1936. The Prostigmatic mites of South African lizards. Parasitology, 28(1): 1-39. https://doi.org/10.1017/S0031182000022228

LOOMIS, R.B.; WRENN, W.J. 1984. Systematics of the pest chigger genus Eutrombicula (Acari: Trombiculidae). In: D.A. GRIFFITHS; C.E. BOWMANN (eds.), Acarology 6, Vol. 1. Chischester, Ellis Horwood, p. 152-159.

MENEZES, V.A.; FONTES, A.F.; GETTINGER, D.; VAN SLUYS, M.; ROCHA, C.F.D. 2011. A morphometric study of Eutrombicula alfreddugesi (Acari: Trombiculidae) infesting foour sympatric species of Tropidurus (Squamata: Tropiduridae) in northeastern Brasil. Phyllomedusa, 10(1): 79-84. https://doi.org/10.11606/issn.2316-9079.v10i1p79-84

MIRANDA, J.P.; COSTA, J.C.L.; ROCHA, C.F.D. 2012. Reptiles from Lençóis Maranhenses National Park, Maranhão, northeastern Brazil. ZooKeys, 246: 51-68. https://doi. org/10.3897/zookeys.246.2593

MORATO, S.A.A.; DE LIMA, A.M.X.; STAUT, D.C.P.; FARIA, R.G.; DE SOUZA-ALVES, J.P.; GOUVEIA, S.F.; SCUPINO, M.R.C.; GOMES, R.; DA SILVA, M.J. 2011. Amphibians and reptiles of the Refúgio de Vida Silvestre Mata do Junco, municipality of Capela, state of Sergipe, northeastern Brazil. Check List, 7(6): 756-762. https://doi.org/10.15560/11015

PAREDES-LEÓN, R.; KLOMPEN, H.; PÉREZ, T.M. 2012. Systematic revision of the genera Geckobiella Hirst, 1917 and Hirstiella Berlese, 1920 (Acari: Prostigmata: Pterygosomatidae) with description of a new genus for American species parasites on geckos formerly placed in Hirstiella. Zootaxa, 3510(1): 1-40.

PRUDENTE, A.L.C.; MAGALHÃES, F.; MENKS, A.; MELO, J.F. 2013. Checklist of lizards of the Juruti, state of Pará, Brazil. Check List, 9(1): 42-50. https://doi.org/10.15560/9.1.42

MARTÍNEZ-RIVERA, C.C.M.; NEGRON, A.G.; BERTRAND, M.; ACOSTA, J. 2003. Hemidactylus mabouia (Sauria: Gekkonidae), Host of Geckobia hemidactyli (Actinedida: Pterygosomatidae), throughout the Caribbean and South America. Caribbean Journal of Science, 39(3): 321-326. 
ROCHA, C.F.D.; CUNHA-BARROS, M.; MENEZES, V.A.; FONTES, A.F; VRCIBRADIC, D.; VAN SLUYS, M. 2008. Patterns of infestation by the trombiculid mite Eutrombicula alfreddugesi in four sympatric lizard species (Genus Tropidurus) in Northeastern Brazil. Parasite, 15(2): 131-136. https://doi.org/10.1051/parasite/2008152131

VAN SLUYS, M.; ROCHA, C.F.D.; VRCIBRADIC, D.; GALDINO, C.A.B.; FONTES, A. F. 2004. Diet, activity, and microhabitat use of two Syntopic Tropidurus species (Lacertilia: Tropiduridae) in Minas Gerais, Brazil. Journal of Herpetology, 38(4): 606-611. https:// doi.org/10.1670/218-03N

VITT, L.; MAGNUSSON, W.E.; ÁVILA-PIRES, T.C.; LIMA, A.P. 2008. Guia de Lagartos da Reserva Adolpho Ducke, Amazônia Central. Manaus, Áttema Design Editorial, 175 p. VRCIBRADIC D.; ROCHA C.F.D.; KIEFER, M.C.; HATANO, F.H.; FONTES, A. F.; ALMEIDA-GOMES, M.; SIQUEIRA, C.; PONTES, J.A.L.; BORGES-JUNIOR, V.N.T.; GIL, L.O.; KLAION, T.; RUBIÃO, E.C.N.; VAN SLUYS, M. 2011. Herpetofauna, Estação Ecológica Estadual do Paraíso, state of Rio de Janeiro, southeastern Brazil. Check List, 7(6): 745-749. https://doi.org/10.15560/11013

\section{Resumo}

\section{Acari de lagartos da Floresta Atlântica no Nordeste do Brasil}

Embora os ácaros estejam frequentemente associados com os répteis, existe pouca informação disponível sobre os parasitas de lagartos no Brasil. O objetivo deste estudo foi identificar os ectoparasitos dos lagartos Kentropyx calcarata (Squamata: Teiidae), Hemidactylus mabouia (Squamata: Gekkonidae) e Tropidurus hispidus (Squamata: Tropiduridae) na região nordeste do Brasil. Os lagartos foram capturados durante a estação seca na Mata de Tejipió, um fragmento de Floresta Atlântica, localizada no município de Recife, estado de Pernambuco, Brasil. Os ácaros Eutrombicula sp. (Acari: trombiculidae), Geckobia hemidactyli e Geckobiella harrisi (Acari: Pterygosomatidae) foram encontrados associados com lagartos adultos de K. calcarata, H. mabouia e T. hispidus, respectivamente. Os ácaros foram encontrados em dobras da pele na região gular e regiões pós-femural (Eutrombicula sp.), "bolsas-de-ácaros" (G. harrisi) e nas regiões axilar, dorsal, ventral e pélvica (G. hemidactyli). No Brasil, este estudo estende a distribuição geográfica conhecida de Geckobiella harrisi em T. hispidus e G. hemidactyli em H. Mabouia. Adicionalmente, Kentropyx calcarata é assinalado como novo hospedeiro de Eutrombicula sp. Esses resultados mostram a importância dos ectoparasitos como uma ferramenta para estudos ecológicos e biogeográficos.

\section{Palavras-chave}

Eutrombicula, Geckobia hemidactyli, Geckobiella harrisi, ácaros, Squamata 